\title{
O homem dos lobos: Deleuze, Guattari e a psicanálise
}

The Wolf-man: Deleuze, Guattari and psychoanalysis

*Larissa Drigo Agostinho

\begin{abstract}
Resumo: apresentamos uma comparação entre leituras distintas (Freud, Lacan e Deleuze \& Guattari) do caso do homem dos lobos visando explicitar e explicar as críticas deleuzo-guattarianas à psicanálise e, por consequência, os limites técnicos e teóricos desta. Serão abordadas as seguintes questões: a centralidade do complexo de Édipo na psicanálise, a castração em Freud e seus significados e limitações e, por fim, o caráter qualitativo da libido. O objetivo desta exposição é apresentar algumas das principais teses da esquizoanálise e expor a relevância de um conceito renovado de inconsciente para a compreensão da relação entre desejo, política e vida social.
\end{abstract}

Palavras-chave: homem dos lobos; esquizoanálise; castração; complexo de Édipo; forclusão.

\begin{abstract}
We present a comparison between distinct readings (Freud, Lacan and Deleuze \& Guattari) of the wolf man case in order to explain the deleuzo-guattarian's critiques of psychoanalysis and, consequently, the technical and theoretical limits of it. The following questions will be addressed: the centrality of the Oedipus complex in psychoanalysis, the castration in Freud and its meanings and limitations, and finally the qualitative character of the libido. The purpose of this paper is to present some of the main theses of schizoanalysis and to expose the relevance of a renewed concept of the unconscious to the understanding the relation between desire, politics and social life.
\end{abstract}

Keywords: Wolf-man; schizoanalysis; castration; Oedipus complex; foreclosure.

\footnotetext{
* Pós-doutoranda no Departamento de Filosofia da Universidade de São Paulo sob a supervisão de Marilena Chauí. <larissa_drigo@yahoo.com.br>.

Pesquisa financiada pela Fapesp.
} 
"Mais si la psychanalyse donc réussit, elle s'éteindra de n'être qu'un symptôme oublié."

(LACAN, La troisième)

\section{Introdução}

Nergueï Pankejeff, que mais tarde se tornaria conhecido como o homem dos lobos, nasceu na Rússia em 1886. Sua história de vida se confunde com a história mesma da psicanálise e da psiquiatria. No começo de sua juventude, por volta dos dezoito anos, ao adoecer gravemente, ele procurou o médico psiquiatra Kraepelin, um dos primeiros teóricos da esquizofrenia. O médico cuidava também do pai de Sergueï. Para o médico, o jovem sofria, como seu pai, de uma psicose maníaco-depressiva. Depois dessa internação, que não obteve sucesso, Sergueï procura Freud, por volta de 1910.

Mas sua história com a análise não termina nesse ponto. Freud interrompe a análise bruscamente e cedo demais, segundo Lacan. Sergueï volta a procurá-lo com alucinações sobre buracos no seu nariz. O psicanalista vienense o encaminha para uma de suas discípulas, Ruth Brunswick. Depois dessa análise, que durou alguns meses, Sergueï passou a encontrar, com frequência, Muriel Gardiner, ao mesmo tempo em que escrevia suas memórias de infância. Muriel publicou o resultado desses encontros informais, da correspondência e das memórias de Sergueï, enquanto esse preparava o seu próprio livro de memórias. Além disso, Karin Obholzer também publicou uma série de entrevistas em Entretiens avec l'homme aux loups. Une psychanalyse et ses suites. Nelas, Sergueï afirma que nunca pode se curar de fato, ele revisa e comenta as análises que fez durante toda sua vida.

O caso do homem dos lobos pode ser considerado mais um dos fracassos retumbantes do processo de cura em psicanálise, ao lado do pequeno Hans e de Dora, mas Sergueï não apenas continuou sendo analisado e próximo do círculo de psicanalistas de escola freudiana, como recebeu uma pensão mensal, até o fim de sua vida, graças a Freud e sua associação.

Buscamos, a partir da análise desse caso, expor algumas das principais críticas de Deleuze e Guattari à psicanálise. Partiremos, para isso, do caso como ele foi teorizado por Freud, em seguida, confrontaremos essa análise com a teoria lacaniana da psicose. Buscaremos expor as limitações da teoria psicanalítica a partir da análise dos conceitos de castração e forclusão, que para Deleuze e Guattari não são capazes de dar conta do caráter eminentemente qualitativo da libido. Através 
desse recurso à esquizofrenia, como maneira privilegiada de sentir, que subverte o paradigma psicanalítico de um inconsciente "falado", expresso na linguagem, instaura-se um materialismo que busca pensar o desejo através de seu funcionamento imanente. Trata-se de ver na esquizofrenia um potencial e não mais uma espécie de déficit de elaboração ou incapacidade de "resolução" do problema da castração. Potencial que diz respeito a um desejo que, mesmo tendo uma potência interna que não cessa de se desdobrar e que, inclusive, dita a natureza de seu funcionamento imanente, nem por isso deixa de ser imune à sua própria destruição ou aniquilação.

O interesse dessa confrontação, entre Deleuze e Guattari, por um lado, e por outro, a psicanálise freudo-lacaniana é expor as consequências, no interior da vida social, de um modelo de organização do desejo que a psicanálise certamente não criou, mas que ela contribui para perpetuar, Édipo. Édipo não depende apenas de um modelo de vida social baseado na família, casal heterossexual-criança, ele é também um mecanismo de circulação e de produção de desejo. Nesse momento será questão de expor uma crítica formal ao Édipo, que no entanto, busca extrair desses princípios formais suas consequências clínicas e políticas. Édipo, depende da heterossexualidade familiar, porque a passagem pelo complexo se confunde com a experiência da castração. Para assumir uma posição em relação ao seu próprio desejo, Freud assume, que o sujeito, ou a criança deve confrontar-se com sua própria sexualidade, ou seja, assumir um sexo para si, uma posição em relação ao desejo da mãe ou do pai e determinar o sexo de suas escolhas de objeto. Sou menino ou menina? Desejo meninos ou meninas? Essa seria a experiência do sujeito diante da castração.

A crítica de Deleuze e Guattari não se limita ao problema de gênero que o binarismo de sexo cria dentro da vida social e no interior da teoria psicanalítica. Ao reduzir o desejo às pessoas organizadas, destruímos o seu caráter imanente, que é de ser social e parcial. Eis a operação que o complexo realiza no próprio desejo, uma limitação, uma redução ao horizonte individual ou no máximo, familiar. O caso do homem dos lobos é, por essa razão, exemplar, pois nos permite compreender o que estava em jogo, inclusive politicamente, na ideia de que o desejo não é uno, mas múltiplo. Melhor seria dizer, arranjos distintos entre multiplicidades. Não se trata apenas de um elogio da força da multitude ou, pior, de sua espontaneidade, mas de pensar o desejo a partir de suas formações sociais, ou seja, de pensar grupos e formas de organização, inclusive e sobretudo políticas. 


\section{No divã do Dr. Freud}

Sonhei que era noite e que estava deitado em minha cama, a janela se abriu sozinha e eu vi, com grande pavor, que alguns lobos brancos estavam sentados na grande nogueira que havia diante da janela. Eram seis ou sete. Os lobos eram inteiramente brancos e pareciam antes raposas ou cães pastores, pois tinham caudas grandes como as raposas e suas orelhas estavam em pé como as dos cães, quando prestam atenção a algo. Com muito medo - de ser devorado pelos lobos, certamente -, gritei e acordei[...]. A única ação do sonho era a abertura da janela, pois os lobos estavam sentados bem quietos nos galhos da árvore, sem nenhum movimento, à direita e à esquerda do tronco, e olhavam para mim. Era como se dirigissem para mim toda a sua atenção. Acho que este foi meu primeiro sonho angustiado. Na época eu tinha três, quatro, no máximo cinco anos de idade. Desde então, e até os onze ou doze anos, sempre tive medo de ver algo terrível nos sonhos (FREUD, 2010, p. 42).

Sergueï Pankejeff, que mais tarde se tornaria o homem dos lobos, adoeceu gravemente aos 18 anos de idade, depois de ter contraído uma gonorreia, um ano após o suicídio de sua irmã Ana. Freud anuncia que tratará o caso como uma neurose infantil que não foi analisada enquanto existiu, mas apenas quinze anos depois de seu fim (FREUD, 2010, p. 15). Após os quatro anos de idade o paciente apresentou um grave distúrbio neurótico, como uma histeria de angústia (zoofobia) que transformouse em neurose obsessiva de cunho religioso e prolongou-se com suas ramificações até os dez anos e meio.

Ele teria sido uma criança afável, dócil, a tal ponto que costumavam dizer que ele era a menina e sua irmã, mais velha, travessa, vivaz deveria ser o menino. No entanto, ele teria se tornado, antes dos cinco anos de idade, uma criança irritadiça, violenta que se encolerizava e "gritava como um selvagem".

Neste período, ele sofria de um medo, do qual sua irmã se aproveitava para zombar dele. Ela o colocava diante de um livro com imagens, uma delas apresentava um lobo em pé, andando a passos largos, Ele ficava horrorizado e gritava com medo que o lobo pudesse comê-lo. Ele também tinha aversão e medo por outros animais, borboletas, besouros, lagartos. Neste período vivia numa propriedade rural, afastada da cidade. No entanto, o paciente também se recordava de ter atormentado esses animais, seccionado besouros, batido em cavalos.

Dito isso, Freud afirma que as lembranças apresentadas em seguida justificam a suposição de uma neurose obsessiva facilmente reconhecível. O paciente teve um período de grande devoção. Rezava durante muito tempo, perfazia o sinal da cruz diversas vezes. No entanto, essa devoção era permeada por pensamentos diabólicos. Sentira-se atormentado, 
quando, numa estação de águas alemã se deparou com três montinhos de cocô de cavalo avistados numa estrada, não podia não pensar na Santíssima Trindade.

Sua relação com o pai tinha sido terna na primeira infância até que a doença deste os afastou. A Nânia, babá com quem o garoto tinha uma relação muito forte, ela o amava como se fosse seu filho perdido, lhe assegurava que ele era do seu pai, como sua irmã pertencia à sua mãe. No final da infância ele parece ter percebido a clara preferência de seu pai pela irmã.

Tudo começa justamente com a irmã e uma cena de sedução que para Freud desempenha um papel fundamental. Ela teria agarrado o membro do menino ao passo que tecia considerações sobre a babá que teria feito o mesmo com o jardineiro, ela o colocava de cabeça para baixo e agarrava suas genitais. Freud insinua que o menino criou diversas fantasias e sonhos, "como se... depois do banho... ele tivesse querido... desnudar a irmã". Essa seria uma resposta contra a sedução da irmã que teria ofendido o "amor-próprio masculino" do paciente. Ele se defendida contra a passividade em que a cena da sedução o colocava sonhando em ser aquele que age, é ativo. "Tais fantasias correspondiam precisamente, então, às lendas com que uma nação que se tornou grande e orgulhosa procura ocultar a pequenez e a desdita de seu começo" (FREUD, 2010, p. 30).

Apesar da metáfora, Freud se recusa a explorar esta via, assim como recusa a teoria de Alfred Adler, que via neste caso uma manifestação da vontade de poder, do instinto de afirmação do indivíduo. Freud afirma que não nega a importância dos motivos do poder e dos privilégios, mas não se convence do seu papel predominante.

Por volta dos catorze anos, a relação entre o paciente e sua irmã melhorou consideravelmente. Na puberdade, ele parece ter buscado uma maior intimidade física com ela. Ao ser rejeitado, ele voltou-se para uma camponesa que servia na casa e que tinha o mesmo nome da irmã. Isso significou um passo decisivo para a "escolha heterossexual de objeto, pois todas as garotas por quem mais tarde se apaixonou, frequentemente com os mais claros indícios de obsessão, eram também criadas, cuja educação e inteligência tinham de estar abaixo das suas" (FREUD, 2010, p. 32). Freud vê nesta escolha de objeto, a busca pela substituição da irmã que o rejeitou. Tal escolha carrega a marca do "rebaixamento da irmã" que visava abolir a superioridade intelectual dela que o oprimira tanto.

Freud (2010, p. 33) conclui que os motivos do poder tinham determinado a escolha de objeto apenas no "sentido de uma contribuição e racionalização", ao que passo que a "determinação verdadeira, mais profunda", o permitia conservar as convicções anteriores. 
Essa motivação, mais profunda, é de natureza "puramente erótica" e está diretamente relacionada à cena primária ou a fantasia do paciente, como veremos.

Antes de apresentar esta cena, Freud desenvolve a consciência da experiência da castração, a ameaça da castração que aparece na cena já citada em que o paciente é tocado pela irmã. A atitude da irmã o coloca em uma posição passiva. A irmã evoca o nome de Nânia, com que o paciente tinha uma relação do tipo mãe-filho, a irmã é substituta da mãe, ela evoca uma posição passiva, feminina, Freud dirá mais, masoquista. A irmã é a identificação feminina do paciente, enquanto que o lobo em pé que o aterrorizava, evoca o pai, a ameaça da castração.

Após a rejeição da irmã, ele passou a brincar com seu pênis diante de Nânia que o ameaçou dizendo que as crianças que faziam este tipo de coisa ficavam com uma "ferida" no lugar. O paciente conta que parou de se masturbar diante dessa ameaça e tornou-se extremamente violento e irritadiço, principalmente com Nânia. A vida sexual do garoto regride à fase pré-genital e adquire um caráter sádico-anal. $\mathrm{O}$ pensamento da castração o ocupava, mas não lhe causava medo, salienta Freud. Os lobos já estavam presentes nas fantasias do garoto. Ele se lembra da leitura de "chapeuzinho vermelho" onde as crianças eram tiradas da barriga do lobo. Seria ele um ser feminino que podia ter crianças no corpo? Neste período, ele começa a praticar crueldades com pequenos animais e a mortificar Nânia que o rejeitara. A meta sádica que a sedução teria lhe dado, "ser tocado nas genitais" parecia ter ficado suspensa. Ele tinha também fantasias em que garotos eram espancados. Nestas fantasias, o órgão sexual mesmo recebe o castigo, o que indica a culpa diante do onanismo, segundo Freud.

Freud afirma que as tendências passivas apareceram depois ou ao mesmo tempo que as sádico-ativas, e acrescenta:

Isso condiz com a insolitamente clara, intensa e duradoura ambivalência do doente, que aqui se mostrou pela primeira vez no desenvolvimento uniforme dos pares de instintos parciais opostos. Esse comportamento permaneceu característico dele também depois, assim como um traço, o de que nenhuma das posições instituídas da libido foi totalmente cancelada por outra posterior. Ela continuava a existir ao lado de todas as demais, o que permitiu a ele uma oscilação constante, incompatível com a aquisição de caráter fixo (FREUD, 2010, p. 38).

Não seria este o sinal mais evidente do caráter limitado do Édipo e da diferença sexual postos pelo complexo e pela castração na compreensão dos processos engendrados pelo inconsciente? 


\subsection{Cena primária ou fantasia}

A interpretação da cena primária se dá graças ao sonho que transformaria o paciente em homem dos lobos. Neste sonho o paciente, que deveria ter mais ou menos quatro anos, vê alguns lobos brancos sentados em uma árvore, eles tinham caudas longas e estavam com as orelhas em pé. O paciente acordou angustiado, "com muito medo de ser devorado pelo lobo (provavelmente pelo pai)" (FREUD, 2010, p. 50).

A brancura dos lobos remete às ovelhas que o paciente ia ver com o pai, quase todas morreram de peste. Já a questão de saber porque os lobos estão na árvore é respondida por uma anedota contada pelo avô, sobre um lobo que invade o atelier de um alfaiate, este por sua vez, pega o lobo pela cauda e a arranca.

Além desta ligação entre o sonho e a castração, Freud (2010, p. 48) completa que a partir de uma análise ainda incompleta do sonho poderia concluir que "o lobo é o substituto do pai", e o sonho trouxe à tona o medo que o pai lhe causara, que teria marcado toda a vida do paciente.

Uma outra lembrança trazida pela análise permite prosseguir a interpretação. A árvore seria a árvore de natal. Como o dia de Natal era também o dia do aniversário do paciente, "pode-se estabelecer com segurança a época do sonho e a transformação dele decorrente". Ele teria adormecido com a expectativa de ganhar dois presentes. Em tais circunstâncias, a criança antecipa a realização de um desejo no sonho. "Mas em vez de presentes havia - lobos, e o sonho findava com ele sentindo medo de ser devorado pelo lobo (provavelmente o pai) e buscando refúgio com a babá" (FREUD, 2010, p. 50). A evolução sexual do paciente permite preencher a lacuna do sonho e esclarecer a mudança da satisfação em medo.

Entre os desejos formadores do sonho, deve ter sido estimulado o mais forte, o da satisfação sexual, que ele ansiava obter do pai. A força desse desejo conseguiu refrescar a pista mnemônica, há muito esquecida, de uma cena que lhe podia mostrar como era a satisfação sexual com o pai, e o resultado foi o pavor, horror ante a realização desse desejo, repressão do impulso que se apresentara por esse desejo, e por isso, fuga do pai, em direção à babá não tão perigosa (FREUD, 2010, p. 50).

Esta cena teria de ser, acrescenta Freud (2010, p. 51), adequada para fundamentar a convicção da existência da castração. Essa cena é a imagem de um coito entre os pais, por trás, repetido por três vezes. A cena permite que a criança visse os genitais da mãe e o membro do pai, e compreendeu, segundo Freud (2010, p. 53) "tanto o fato quanto a significação". 
O lobo, que a criança teria visto nos contos infantis, em pé, e que lhe causava tanto pavor, lembrava a posição do pai nesta cena. Se o lobo do qual o paciente tinha medo era o pai, este medo estava ligado à postura erguida, a imagem do lobo andando com as quatro patas, ou deitado na cama, não lhe causava medo. Essa afirmação, no entanto, parece contradizer o sonho e a angústia por ele provocada por lobos sentados. No entanto, Freud prossegue afirmando que a posição ocupada pela mulher na cena primária não tinha uma significação menor, já que o mais singular fenômeno da vida amorosa do paciente eram "acessos de paixão sensual compulsiva", que surgiam e desapareciam misteriosamente, e que escapavam completamente de seu controle. A mulher tinha que adotar "a posição atribuída à mãe na cena primária", o paciente se interessava por mulheres com traseiros grandes e salientes e uma relação sexual que não fosse nesta posição dificilmente o agradava.

Assim, da cena primária, cuja veracidade não coloca problemas para Freud, afinal esta cena é também uma fantasia sexual do paciente que parece esclarecer o sonho com os lobos e a fobia que teria marcado sua infância. Freud esclarece o sonho do menino, inteiramente, a partir das seguintes relações: "anseio de satisfação sexual com o pai - inteligência da condição a ela relacionada, a castração - medo do pai".

Desta cena primária, "não partiu uma única corrente sexual, mas toda uma série delas, verdadeiramente uma fragmentação da libido" (FREUD, 2010, p. 62). Séries e fragmentações que não escapam da observação atenta de Freud, que as identifica da seguinte maneira: a angústia produzida pelo sonho era uma "recusa do desejo de satisfação sexual com pai". Essa atitude passiva para com a pai que coloca o menino no lugar da mãe tinha sido reprimida e a angústia diante do pai tomou a forma do medo de lobos.

Em nenhum momento Freud imagina que o menino se identificava com os lobos que o espreitavam como esperando de seu "eu" uma resposta frente as séries e fragmentações, que o sonho colocava diante dele. Aqueles lobos, que assumem ao longo da análise diversas formas e posições, figuram séries de possibilidades e modos de relação do sujeito com seu desejo. Freud vê neles apenas a imagem do pai e a angústia do menino diante da posição feminina, passiva, que desde a sedução da irmã, ele desejava compulsivamente.

Freud continua afirmando que durante o sonho o menino se identificou com a mãe castrada e agora se rebelava contra isso: "Se você quer ser satisfeito pelo pai, você deve aceitar a castração, como a mãe; mais isso eu não quero". Um claro protesto de sua masculinidade!" (FREUD, 2010, p. 65). 
Assumir uma posição diante do desejo implica lidar com as perdas provocadas por essa escolha única. No caso do menino, diante da castração, a posição da mulher aparece como algo repulsivo, ela ativa a "libido genital narcísica", o menino protesta contra a renúncia ao seu membro que este tipo de satisfação, "feminina", passiva, parece implicar. O sonho permite a reorganização sexual do menino. Até então ele oscilava entre passividade e atividade, desde a sedução sua meta sexual era passiva, e transformou-se, "pela regressão ao estágio anterior da organização sádico-anal, em masoquista", ser castigado, golpeado. Neste momento era indiferente se a meta seria alcançada com um homem ou uma mulher. Era na fantasia de ser golpeado no pênis que se exprimia, segundo Freud (2010, p. 65), o nexo da regressão. A relação entre o sonho e a cena primária o leva de volta à organização genital. "Ele descobriu a vagina e a significação biológica de masculino e feminino". Isso significa que ele "compreendeu que ativo era igual a masculino, e passivo a feminino".

O que o motiva a assumir escolhas de objeto heterossexual é a imagem que torna possível a afirmação de sua masculinidade que não é nada além do efeito provocado pelo medo da castração ou de sua possibilidade. Frente à ameaça ele assume uma posição ativa, mas apenas quando a parceira está numa posição "rebaixada". Como se fosse insuportável que outro, que não ele mesmo, ocupasse a posição do lobo, em pé, que tanto o atemorizava na infância. Se o lobo o assustava tanto, esse medo não poderia ser a expressão de uma recusa em relação a esta posição? Freud entende que este medo é medo do pai e da castração que implicaria, para o menino, assumir a posição feminina.

No entanto, não haveria um problema com essas identificações entre feminino e passividade e, por outro lado, masculino e atividade? Não seria justamente essa a causa da angústia do menino, que diante do psicanalista via reatualizar-se uma moral que identifica atividade/ passividade a possessão de genitais masculinos ou femininos? A questão não seria justamente a impossibilidade do paciente de encontrar lugar para o seu desejo diante dessas dicotomias tão rígidas e socialmente e biologicamente determinadas, intrincando posições sexuais, relações familiares, a partir de diferenças biológicas? Não seria justamente a rigidez destas posições que provocava a "insolitamente clara, intensa e duradoura ambivalência" do paciente?

Em Análise terminada e análise interminável, verdadeiro testamento freudiano, o psicanalista reconhece que tudo iria bem se o problema econômico do desejo fosse apenas qualitativo, a questão seria apenas reforçar o eu contra as pulsões. No entanto, existem fatores qualitativos na economia desejante, que se colocam como obstáculo à cura e que Freud 
se recrimina de não ter examinado atentamente (DELEUZE; GUATTARI, 1972, p. 80).

Neste recenseamento dos obstáculos à cura, Freud aponta três fatores. O primeiro é a "rocha" da castração, verdadeiro muro com suas duas vertentes não simétricas (derivadas do par feminino/masculino) e que introduz um alvéolo incurável em torno do qual a cura erra. O segundo obstáculo seria a atitude qualitativa em relação ao conflito que faz com que a libido não se divida em duas forças variáveis correspondendo à homossexualidade e à heterossexualidade, mas crie, na maioria das pessoas, oposições que são irredutíveis à essas duas forças. Finalmente, o terceiro, de uma importância tal que dispensa as considerações dinâmicas e tópicas, diz respeito a um tipo de resistência não localizável: diríamos que certos sujeitos tem uma libido tão viscosa, tão líquida que nada os "pega" (DELEUZE; GUATTARI, 1972, p. 80-81).

Ora, não são essas as principais características do homem dos lobos? Não são justamente esses fatores que tornaram sua análise interminável, a ponto de ele reclamar, no fim da sua vida, que a análise não serviu de nada?

O que é grave, para Deleuze e Guattari, é que Freud não tenha sido capaz - mesmo diante destes obstáculos, mesmo tendo chegado ao ponto de reconhecer que a análise podia não terminar - de colocar em questão o processo de cura. Ele não interpreta esses fatores como obstáculos, mas como insuficiências, efeitos ou contra efeitos da cura (DELEUZE; GUATTARI, 1972, p. 82)

Para Deleuze e Guattari a castração como analisável (inanalisável, "rocha" última) é na verdade, efeito da castração como ato psicanalítico. A homossexualidade edípica é efeito da edipianização, que a cura certamente não cria $^{1}$, mas que ela precipita e acentua nas condições que são as suas (transferência). E, quando a libido resiste à cura, não se trata de uma resistência do eu, mas do clamor da produção desejante. (DELEUZE; GUATTARI, 1972, p. 82). É assim que Deleuze e Guattari procederam no exame do caso do homem dos lobos. Postos os limites do conceito de castração e de sua pertinência, dado o caráter limitado das posições binárias e excludentes masculino/feminino, passivo/ativo, homossexualidade/heterossexualidade somos levados a encarar o caráter qualitativo da libido, essa que de tão líquida, de tão ambivalente parece

\footnotetext{
É importante salientar que a crítica deleuziana não consiste em afirmar que Édipo é uma "ficção freudiana", é justamente este o problema político em torno da questão. Deleuze e Guattari insistem na necessidade do familiarismo na produção dos indivíduos contemporâneos. Daí o caráter "repressor" da redução do inconsciente ao triângulo edípico que cinde questão libidinal e vida social e política, ou economia libidinal e economia política.
} 
resistir à cura, encontramos, no caso do homem dos lobos, o sonho, os lobos, o nome que lhe seria próprio, sua máquina desejante.

O objetivo da esquizoanálise e de sua crítica à psicanálise, pois esse é um dos seus momentos fundamentais, é atingir os investimentos de desejo inconsciente no interior do campo social, e para isso ela conta com indícios, indícios que podem ser encontrados na sexualidade. O homem dos lobos parece manifestar um gosto decisivo pela mulher pobre, a camponesa de quatro lavando roupas, a empregada lavando o chão. A questão aqui é saber se esses investimentos sexuais-sociais da libido e suas escolhas de objeto devem ser tomados como simples dependência de um Édipo familiar. (DELEUZE; GUATTARI, 1972, p. 428). Devemos ver essas mulheres como compromisso e substitutas diante da proibição do incesto? Freud escolhe essa opção ao afirmar que a criança se coloca acima das diferenças sociais que, para ele, não significam muita coisa, ele classifica as pessoas de classe social inferiores na série parental quando essas pessoas o amam como o amam seus pais.

Deleuze e Guattari (1972, p. 429) recusam a interpretação freudiana, segundo a qual, as mulheres de outra classe seriam uma imagem "rebaixada" da mãe, porque para eles a outra classe é apreendida pela libido como "estranha, não-mãe, não-pai, não-família, indício do que há de não humano no sexo". Esse elemento não humano é fundamental para a constituição das máquinas desejantes. Não se trata aqui de negar a importância do coito entre os pais ou da posição da mãe nesse coito. Mas quando essa posição remete a uma camponesa ou a um animal o que autoriza Freud a fazer valer esses substitutos pela mãe, ignorando a diferença social ou genérica?

A crítica à psicanálise visa em primeiro lugar mostrar que o complexo de Édipo transforma fantasmas e fantasias de grupo em problemas individuais, de um "eu" que se organiza a partir do triângulo familiar. Os lobos, por exemplo, são reduzidos a uma unidade, para em seguida serem assimilados à figura paterna que porta consigo a ameaça da castração. No momento mesmo em que a psicanálise descobre a libido, separando sexualidade e reprodução, o complexo de Édipo centraliza essa energia livre. Todos os agentes da produção e da antiprodução social são reduzidos às figuras da reprodução familiar (DELEUZE; GUATTARI, 1972, p. 79).

É a castração e sua relação com o complexo de Édipo que funda o uso exclusivo das disjunções: "você é menina ou menino". Ela funciona, ao mesmo tempo, como o solo comum, o Falo preponderante e transcendente e a exclusiva distribuição que se apresenta nas meninas como desejo do pênis e, nos garotos, como medo de perdê-lo, ou recusa da posição passiva. O Falo ou a Falta tem como função nos ensinar a resignação. 
Resignação ao Édipo, à castração, renúncia para as meninas do desejo do pênis, dos meninos "protesto da masculinidade", o sexo aceito e assumido. A sexualidade reduzida à relação sexual e limitada à sua forma antropomórfica. Este falo transcendente, ou a falta só pode ser de origem mítica, "ele é o Um da teologia negativa, ele introduz a falta no desejo, e faz emanar as séries exclusivas às quais ele fixa um objetivo, uma origem e um curso resignado" (DELEUZE; GUATTARI, 1972, p. 73).

Édipo não é apenas resultado de um processo de individualização da libido, ou uma redução da vida social à família e seus personagens sexuados, que provoca a limitação da sexualidade à sua forma antropomórfica e reduz o desejo à esta forma limitada. Todas essas características, ou consequências do complexo, são resultado de uma submissão da produção desejante às exigências da representação. $\mathrm{O}$ inconsciente produtivo desaparece para dar lugar a expressão (ça parle!), apresentando-se sob a forma do mito, da tragédia e do sonho. $\mathrm{O}$ inconsciente produtivo se transforma em um palco teatral onde os fantasmas e as expressões se desenrolam. Assim, Freud passa da cena primária para a fantasia, pois pouco importa se o homem dos lobos viu a cena, se a cena era entre seus pais ou dois cachorros, pois a fantasia se determina pela escolha de objeto, pelos indícios sexuais aplicados à família.

Assim, "O primeiro erro da psicanálise é acreditar que tudo começa com a criança". Essa assunção a leva a desenvolver uma "teoria absurda da fantasia" no interior da qual o pai, a mãe, suas ações e paixões reais são compreendidas como "fantasia" da criança (DELEUZE; GUATTARI, 1972, p. 331) Essa regressão enclausura o desejo dentro de um sistema de reprodução, ou geração, atingindo apenas, com os corpos orgânicos e as pessoas organizadas, o objeto da reprodução, mas não seu verdadeiro sujeito, o processo de autoprodução do inconsciente.

E o homem dos lobos não cessava de dizer a Freud que seus sonhos não se encaixam nos sonhos do psicanalista. Ao comentar sua análise, ele afirmou que não concordava com a cena primária, "ele não acreditava", mas isso não dizia respeito à questão de saber se de fato ele presenciou os pais no momento da relação sexual. Ele não acredita na interpretação pelo sonho da cena primária, ele não acredita nas hipóteses de Freud que diziam respeito a uma masculinidade que teria recalcado impulsos homossexuais, porque a fase da sedução teria determinado a posição masoquista do sujeito, ou seja, passiva.

Ao afirmar que não só não se lembrava da cena primária, a visão da relação sexual entre os pais, como ela teria sido impossível na Rússia czarista, Serguei afirma "do que aconteceu entre minha irmã e eu, eu me lembro. Eu não consegui me lembrar das outras coisas, do que ele 
relacionava aos lobos. Mas isso eu sei: ela era agressiva, e é por isso que o complexo nunca desapareceu; ele continuou a agir de uma maneira ou de outra" (OBHOLZER, 1981, p. 71).

Ele compreendeu perfeitamente a questão de Freud. Ele certamente concordava com a importância da sedução da irmã, de seu interesse por ela, e da rejeição. No entanto, talvez o que ele tenha deixado claro na análise posterior com Bruckwig é que ele não estava disposto a aceitar a interpretação de Freud no que diz respeito à "passividade". A sedução teria determinado uma posição passiva que colocava o sujeito diante da ameaça da castração que a identificação com a mãe provocaria. O homem dos lobos insistia justamente neste ponto. Na cena primária que Freud utiliza para explicar a fantasia, com mulheres, de quatro, com o gosto do homem dos lobos por mulheres com nádegas protuberantes. Da mesma maneira que ele afirma não se lembrar das coisas que Freud relacionava aos lobos, como a cena primária, ele se pergunta "na minha história, o que foi explicado pelos sonhos, em definitivo? Eu não saberia dizer. Freud relaciona tudo à cena primária, que ele deduz do sonho. Mas no sonho ela não aconteceu." (OBHOLZER, 1081, p. 70).

Antes de passarmos à análise deste sonho empreendida por Deleuze e Guattari, vejamos como Lacan analisa o caso do homem dos lobos.

\section{No divã do Dr. Lacan}

Lacan critica Freud por ter estipulado um fim para a análise do homem dos lobos. Essa ruptura brusca teria privado o paciente do tempo para compreender. A confirmação da alienação do sujeito em relação a verdade do seu desejo se evidencia pela incapacidade do homem dos lobos integrar a cena primitiva em sua história pessoal (como vimos ele não acreditava). Mais tarde, na análise com Bruckwig, sobretudo, essa alienação aparece da forma mais categórica, como paranoia.

Mais um fato interfere na análise, o dinheiro, que por iniciativa de Freud é versado para o homem dos lobos até o fim de sua vida (esse dinheiro é produto de uma coleta entre psicanalistas, agradecimento pelos serviços prestados à causa, que para Lacan, só evidencia a alienação do sujeito de sua verdade). Podemos reconhecer, segundo Lacan (1966, p. 310-311), na insistência de Freud em voltar a esse caso, uma subjetivação não resolvida que deixa em suspenso e que terá grande influência na psicose que se seguirá.

Lacan discute, a partir deste caso, o seguinte problema: a manutenção do recalcado, apesar da tomada de consciência do recalcado. A questão aqui é também explicar a regressão que leva o paciente do acesso à fase genital, conquistada não sem certa audácia, para a fase anal. A 
razão deste fenômeno está, para Freud, na posição feminina assumida pelo sujeito na captação imaginária do traumatismo primordial. Ela torna impossível aceitar a realidade genital sem a ameaça inevitável da castração. Mas, o que Freud nos diz sobre a natureza deste fenômeno é ainda mais interessante, segundo Lacan. Não se trata aqui de um recalcamento porque esse implica retorno do recalcado, aquilo sobre o qual o sujeito não pode falar grita por todos os poros. Este sujeito não queria saber nada da castração, mas não como um recalcamento e sim como um "rettranchement" (do verbo retrancher, literalmente recortar), ou forclusão (Verweifung). Seu efeito é uma abolição simbólica (LACAN, 1966, p. 387).

Para que o sujeito negue algo, sob a forma do recalcamento, é preciso que o recalcado tenha aparecido sob a forma da simbolização primordial. O que ocorre no caso da forclusão é que o que não aparece no simbólico, o que não ascende à simbolização, retorna no real. $\mathrm{E}$ é exatamente isso o que Lacan vê em uma alucinação do homem dos lobos analisada por Freud (LACAN, 1966, p. 388).

Devido à forclusão, a castração erraticamente aparece no real, nas relações de resistência sem transferência, como uma pontuação sem texto. O real está ali, agora, para fazer eclodir o que o princípio de realidade nomeia "mundo exterior". O caráter anal da forclusão se faz sentir, "trata-se da questão do dentro e do fora". A forclusão não é um julgamento que rejeita e escolhe. O que o sujeito forclui é uma abertura ao ser, por isso, nada do que foi forcluído pode encontrar lugar na sua história, se designarmos assim o lugar onde o recalcado pode aparecer. A forclusão, ao bloquear o processo de simbolização, atinge diretamente à Bejahung que Freud entende como processo primário, onde o julgamento atributivo tem suas raízes, e que não é nada além da condição primordial para que do real alguma coisa possa oferecer-se à revelação do ser, ou para empregar outro termo heideggeriano que Lacan menciona, "soit laissé être". É para este ponto tão distante que Freud nos leva.

É Freud quem descreve, ditado pelo homem dos lobos, essa alucinação: ele conta que quando tinha cinco anos brincava no jardim próximo de sua babá e fazia cortes em uma árvore (da qual sabemos o papel em seu sonho). De repente, ele percebeu, com um terror indescritível, que ele havia cortado o menor dedo da mão (direita ou esquerda? Ele não sabe) e que esse dedo estava pendurado apenas pela pele. Ele não sentia nenhuma dor, mas uma grande ansiedade. Ele não era capaz de dizer nada à babá que estava ao seu lado, deixou-se ficar em um banco e permaneceu assim, incapaz de olhar mais uma vez seu dedo. No final, ele se acalmou e pode olhar bem para o seu dedo, e olhem isso, ele estava ileso. 
Um eco imaginário surge, diz Lacan (1966, p. 392), "em resposta a um ponto da realidade que pertence ao limite onde ele foi recortado (forcluído) do simbólico". Essa errância que se repete e ecoa é da natureza da forclusão, ela é dupla, retrancher, indica também recortar, recosturar, retraçar, refatiar. Essa aparição, o conteúdo da alucinação, massivamente simbólico, "deve sua aparição no real ao fato de que ele não existe para o sujeito".

A forclusão da castração significaria, portanto, à negação da existência daquilo que permitiria que o sujeito fosse. Essa simbolização faltante se deve ao fato de que permaneceu fixado no inconsciente do homem dos lobos uma posição feminina imaginária que bloqueia todo sentido de sua mutilação alucinatória.

$\mathrm{Na}$ ordem simbólica, os vazios são tão significantes quanto os plenos, "ouvindo Freud hoje, poderíamos dizer que é na lacuna de um vazio que se constituem os primeiros passos de seu movimento dialético". Isso explica a insistência do esquizofrênico a "reiterar seus passos" (Lacan, 1966, p. 392). Em vão, porque seu discurso está privado de dialética. ${ }^{2}$

O paranoico, por outro lado, sofre com a retroação cíclica que torna tão difícil a anamnese de seus distúrbios (troubles), fenômenos elementares, pré-significantes que se tornam capazes, após uma organização discursiva longa e difícil de estabelecer, de constituir esse universo tão parcial que é o delírio.

Lacan parece ter, citando Heidegger, dado um grande passo em relação à Freud, e ele é decisivo para as críticas de Deleuze e Guattari. Críticas que acusam a psicanálise de fabricar uma patologia, que, como vimos, priva o sujeito de uma "abertura ao ser". Ele está para sempre privado de uma simbolização, de um recalque fundamental que o colocaria no interior da vida social. Assim, esse diagnóstico se apresenta como sentença de exclusão social que destina o esquizofrênico a viver fora dos limites determinados pela ordem social. Haveria outra maneira de compreender afirmações lacanianas como essa, segundo a qual podemos na loucura "reconhecer a liberdade negativa de um fala que renunciou ao reconhecimento"? (LACAN, 1966, p. 279).

Um dos subcapítulos de "Função e campo da fala e da linguagem", trata do símbolo e da linguagem como estrutura e limite do campo psicanalítico. Ela pode nos auxiliar a delimitar os campos e problemas nas divergências entre Lacan e Deleuze e Guattari, quanto à natureza da esquizofrenia.

2 Sobre o caso do homens dos lobos, pensado a partir de uma perspectiva lacaniana, ver: Sauret Marie-Jean, "Les Hommes aux loups", Psychanalyse, 2, 1 (2005), p. 53-82, e , do mesmo autor, "Les 'loupés' de l'Homme aux loups", Psychanalyse, 21, 2 (2011), p. 5-20. 
Para Lacan (1966, p. 276), a descoberta da psicanálise é a descoberta "do campo das incidências, na natureza do homem, de suas relações à ordem simbólica", e a ereção de seu sentido até as instâncias mais radicais da "simbolização no ser". O símbolo torna o homem o que ele é: "O homem fala porque o símbolo o tornou homem". A linguagem indica as relações que o homem tece com a ordem simbólica, como ele se comporta no interior de uma estrutura e quais os limites de sua vida e ação no interior da ordem social. "É por esta razão que o complexo de Édipo, enquanto o reconhecemos sempre por cobrir de sua significação o campo interior da nossa experiência", é visto como responsável por "marcar os limites que nossa disciplina assigna à subjetividade", ele "concerne o que o sujeito pode saber sobre sua participação inconsciente no movimento das estruturas complexas de aliança, verificando os efeitos simbólicos na sua existência particular e no movimento tangencial na direção do incesto que se manifesta desde o advento de uma comunidade universal" (LACAN, 1966, p. 277).

Esta lei, simbolizada por Édipo, se faz reconhecer como idêntica a uma ordem da linguagem. É "no Nome do Pai que podemos reconhecer o suporte da função simbólica que identifica sua pessoa à lei" (LACAN, 1966, p. 278). Concepção que permite distinguir claramente na análise os efeitos inconscientes dessa função com as relações narcísicas e com as relações reais que o sujeito sustenta com a imagem e a ação da pessoa que o incarna.

Os símbolos envolvem a vida do homem como uma rede absolutamente total desenhando seu destino, lhe dando as palavras que o tornarão fiel ou renegado, a lei dos atos que ele seguirá "até onde ele ainda não é e além da sua morte" (LACAN, 1966, p. 279). O símbolo oferece a servidão e a grandeza onde o vivaz "se aniquilaria se o desejo não preservasse sua parte nas interferências que fazem convergir sobre ele os ciclos da linguagem, quando a confusão das línguas se mistura e as ordens se contrariam fissurando a obra universal" (LACAN, 1966, p. 279). No entanto, apesar da confusão das línguas e das fissuras possíveis em relação a ordem simbólica, o desejo que aqui emerge, para ser satisfeito, exige, segundo Lacan, reconhecimento, pelo acordo da fala ou pela luta pelo prestígio, no simbólico ou no imaginário. A questão da psicanálise "é a emergência no sujeito do pouco de realidade que esse desejo sustenta em relação aos conflitos simbólicos e imaginários como meio de seu acordo, e sua via é a experiência intersubjetiva onde esse desejo se faz reconhecer" (LACAN, 1966, p. 279).

Três paradoxos se instauram. Primeiramente, Lacan (1966, p. 280) poderá afirmar que na "loucura, seja qual for a sua natureza", podemos "reconhecer a liberdade negativa de um fala que renunciou ao reconhecimento", que coloca obstáculo à transferência. Por outro lado, 
a formação singular do delírio objetiva o sujeito em um discurso sem dialética. Estamos diante de um discurso onde o sujeito é falado. Os símbolos do inconsciente apresentam-se sob formas petrificadas que o sujeito, como no caso da neurose, não assume.

O segundo caso é representado pelo campo privilegiado da descoberta psicanalítica: o sintoma, a inibição, a angústia na economia de diferentes neuroses. O sintoma é evidentemente "o significante de um significado recalcado na consciência de um sujeito" (LACAN, 1966, p. 280).

O terceiro paradoxo instaurado pela relação da linguagem e a fala é o do sujeito que se perde nas objetivações do discurso. O eu moderno que toma sua forma nos impasses da dialética da bela alma que não reconhece a razão de seu ser na desordem do mundo. O que faz a responsabilidade questionável da psicanálise é que, com suas manipulações místicas, ela cria uma ocasião suplementar para o sujeito se alienar na trindade do ego, superego e id (LACAN, 1966, p. 282). Se a análise tem como objetivo o "surgimento de uma fala verdadeira e a realização pelo sujeito de sua história em relação ao futuro" (LACAN, 1966, p. 282), ela precisa, antes de mais nada, distinguir o eu da presença daquele que fala ao analista.

Ou seja, colocar o símbolo e a linguagem como limite do campo psicanalítico implica que a loucura aparece como problema, porque ela escapa da dialética, da linguagem, do simbólico e, consequentemente, da ordem estrutural. $O$ destino do esquizofrênico parece ser a catatonia. A segunda consequência o coloca fora do campo da sintomatologia psicanalítica porque onde não há recalque, não há sintoma. A forclusão implica na alucinação e no delírio, cuja lógica, mais uma vez, escapa ao que Lacan entende por linguagem. ${ }^{3}$ Por fim, os impasses anteriores parecem conduzir a uma conclusão que Deleuze e Guattari poderiam partilhar: a necessidade de encontrar um espaço na teoria e na vida social para a emergência de um sujeito que não corresponde à figura do "eu".

Lacan e Deleuze e Guattari traçaram vias distintas para responder a esta questão. Para falar brevemente, a partir do exemplo da castração, que Lacan transformará completamente, ela terá como função clínica

\footnotetext{
3 Segundo Florent Gabon-Garcia entre os anos sessenta e setenta na França a teoria lacaniana da forclusão é dominante entre psicanalistas, como atesta a tese de Serge Leclaire, Principes d'une psychothérapie des psychoses. O autor defende que quando o Nome do Pai é forcluído não resta grande coisa a fazer. Nesta perspectiva, o diagnóstico parece "reificar o doente, e o efeito de grupo, que o observa silenciosamente, contribui para o agravamento do seu estado". Apesar dos problemas com o diagnóstico, o mestre Lacan seria contestado pelos seus pares apenas no final do século XX, (com exceção, evidentemente de Guattari). Para mais detalhes, ver: GabarronGarcia Florent, “'L'anti-oedipe', un enfant fait par Deleuze-Guattari dans le dos de Lacan, père du 'Sinthome'”, Chimères, 72 (1/2010), p. 303-320. Disponível em: <http://www.cairn. info/revue-chimeres-2010-1-page-303.htm>. Consultado em 14 de fevereiro de 2017. Sobre o debate entre Deleuze, Guattari e Lacan, ver também Sophie Mendleshon, "Jacques Lacan, Gilles Deleuze, Itinéraire d'une rencontre sens lendemains", L'évolution psychiatrique, Paris, 69 (2004).
} 
tornar possível a inscrição de um sujeito, porque seu gesto será esvaziado até tornar-se simplesmente negativo. Para Lacan a castração é o que faz com que o inconsciente seja estruturado como uma linguagem. Ela indica a inscrição metonímica do desejo numa cadeia significante. Ela aparece nesse caso como inscrição de uma falta, já que a entrada do desejo na cadeia significante só pode ser parcial. Para Lacan a psicanálise fala em nome da castração quando essa falta estrutural do desejo dissolve as representações imaginárias, os impossíveis que guiam o desejo sob a forma da representação. Assim, ela é o negativo que dissolve as representações e torna possível a emergência de um sujeito. Esse sujeito que emerge na clínica através de um processo eminentemente negativo, como ele funciona? O que é capaz de produzir? A questão deleuzo-guattariana é saber que desejo é esse que se libera das ilusões que o fizeram errar.

Para Deleuze e Guattari (1972, p. 103), as críticas lacanianas ao complexo de Édipo, presentes em afirmações como "a psicanálise não é o rito de Édipo" deveriam ser ouvidas pelos psicanalistas, mas ao mesmo tempo, "ascender das imagens à estrutura, das figuras imaginárias às funções simbólicas, do pai à lei, da mãe ao grande Outro", só nos levaria a recuar na questão edípica. Sobretudo, quando o abandono de Édipo não é o abandono da castração. "Seria possível denunciar Édipo como um mito, e no entanto, manter que o complexo de castração, não é um mito, mas ao contrário, algo de real?"

O que Deleuze e Guattari colocarão em questão é justamente o lugar do símbolo e da estrutura, ou da linguagem na constituição do campo psicanalítico. O que como vimos, incide diretamente no conceito de esquizofrenia. Se Lacan coloca o símbolo no limite de seu campo, assim como a linguagem, o esquizofrênico renuncia à fala facilmente reconhecível, a transferência não se instaura, o que significa que ele está excluído do campo psicanalítico e sua linguagem o exclui também da vida social porque se coloca fora do espaço do reconhecimento.

O objetivo da crítica de Deleuze e Guattari, em Anti-Édipo, consiste em determinar como e quais as consequências da transformação de Édipo em dogma ou "complexo nuclear". Vimos com Freud que Édipo dá conta para cada sujeito de um ou outro sexo, de uma série de pulsões, afetos e relações que unem a forma positiva do complexo à sua forma invertida ou negativa, o que permite ligar as fases pré-edípicas (neuroses ou fobias infantis) ao complexo negativo. Mas o problema é ainda maior. A interpretação estrutural fez de Édipo um "símbolo católico universal", além de toda e qualquer modalidade imaginária.

Édipo é referência para as fases pré-edípicas, exo-edípicas e paraedípicas. Tomemos o exemplo da forclusão. Ele indica uma lacuna 
estrutural, através da qual o esquizofrênico é naturalmente recolocado no eixo edípico na perspectiva de três gerações. A mãe não foi capaz de colocar o seu desejo em relação ao próprio pai, nem o filho em relação à mãe. "Um discípulo de Lacan pode escrever: consideraremos 'os modos através dos quais a organização edípica desempenha seu papel na psicose; em seguida, quais são as formas de pré-genitalidade psicótica e como elas podem sustentar a referência edípica'" (DELEUZE; GUATTARI, 1072, p. 64).

Neste contexto, a crítica de Deleuze e Guattari pode parecer superficial e mesquinha, como se ela se limitasse à construção imaginária de Édipo e às figuras parentais, sem jamais tocar a estrutura e sua ordem e função simbólica. Mas, a questão aqui é saber se a diferença passa pela relação simbólico/imaginário, ou se ela pode ser reduzida a essa relação.

A verdadeira diferença não estaria entre Édipo, estrutural assim como imaginário, e alguma outra coisa, que todos os Édipos aniquilam ou recalcam: ou seja, a produção desejante - as máquinas do desejo que não se deixam reduzir à estrutura nem as pessoas e que constituem o próprio Real, além ou aquém do simbólico assim como do imaginário? (Deleuze; Guattari, 1072, p. 64).

Deleuze e Guattari colocam essa pergunta à teoria lacaniana. Será que o pensamento de Lacan buscou mesmo edipianizar a esquizofrenia, ou trata-se na verdade, do contrário, de esquizofrenizar o campo do inconsciente e o campo social e histórico para evidenciar os limites de Édipo, para encontrar a força das produções desejantes e religar no real os laços que unem máquina analítica, desejo e produção? "Porque o inconsciente não é mais estrutural que pessoal, ele não simboliza mais do que imagina ou figura: ele maquina, ele é maquínico. Nem imaginário, nem simbólico, ele é o real nele mesmo" (DELEUZE; GUATTARI, 1072, p. 65).

E é deste ponto de vista que Deleuze e Guattari tratarão da esquizofrenia. Segundo os autores, a psicanálise e a psiquiatria encontram grande dificuldade para dar conta da esquizofrenia sem reduzi-la a um déficit ou destruição que ela supostamente engendraria na pessoa, ou as lacunas ou dissociações que ela provoca em uma suposta estrutura. Dificuldade que se resume em dar conta da positividade mesma da esquizofrenia. Dificuldade de compreender a esquizofrenia em sua positividade como processo produtor de construções singulares, um processo que pode, no entanto, resultar em catatonia, e eis o que deve ser evitado (DELEUZE, 2003, p. 23).

A psicanálise não consegue sair deste ponto de vista negativo porque ela tem com a psicose uma relação ambígua. Por um lado, ela 
sente que seu material está na psicose, é verdade para Freud, Lacan, ou Melanie Klein. Por outro lado, o método psicanalítico é totalmente construído com base na neurose, e por essa razão encontra grandes dificuldades para ter acesso ao que é da ordem da psicose. É justamente o método psicanalítico, a clínica e seu modo de funcionamento inclusive institucional que será colocado em questão, sobretudo a questão de saber o que é a cura.

Freud propõe uma distinção simples entre neurose e psicose, segundo a qual a realidade é salva na neurose com uma condição, o recalque do "complexo de Édipo", já na psicose o princípio de realidade se perde porque a libido recusa o mundo exterior. $\mathrm{O}$ eu se volta para si mesmo. Freud via no que chamava de "megalomania" uma das características distintivas da psicose.

Já Lacan, como vimos, estabelece uma distinção entre o recalque neurótico que se exerce sobre o significante e a forclusão psicótica que se exerce sobre a ordem simbólica no plano original do significante, espécie de buraco na estrutura, lugar vazio que faz com que o que foi forcluído no plano simbólico retorne no real sob a forma de alucinações.

O ponto de vista continua negativo porque a questão da psicanálise é saber o que falta no psicótico para que o mecanismo psicanalítico funcione. Isso se reduz, grosso modo, para a psicanálise, a questão de saber se o que falta ao esquizofrênico depende do complexo de Édipo. Seria a esquizofrenia uma desfiguração do papel materno e uma aniquilação do pai, que explicam a existência de uma lacuna na estrutura edípica?

Deleuze e Guattari não acreditam que uma estrutura familiar, mesmo que estendida a três gerações, seja uma boa medida para a compreensão da esquizofrenia, sobretudo porque ela continuaria dependente de uma relação negativa, ela continua sendo posta de maneira negativa, como um déficit de "elaboração".

Colocar em questão a centralidade do complexo significa, não apenas colocar em questão os pares biunívocos que dele derivam (feminino/masculino, passivo/ativo, masoquista/sádico, homossexual/ heterossexual), mas também as identificações (papai-mamãe) que ele implica. Deleuze e Guattari (2003, p. 25) insistem justamente neste ponto, nas identificações operadas pelo esquizofrênico. Basta examinar a natureza do delírio psicótico para que se averigue que o delírio "nunca é a reprodução mesmo que imaginária de uma história familiar em torno de uma falta. É, pelo contrário, um demasiado-cheio de história, uma vasta deriva na história universal. O que o desejo fomenta é as raças, as civilizações, as culturas, os continentes, os reinos, os poderes, as guerras, as classes e as revoluções. E não é preciso ser culto para delirar nesse sentido. Sempre há um crioulo, um judeu, um chinês, um grande mongol, 
um ariano no delírio; todo delírio é político e econômico. E não se trata apenas da expressão manifesta do desejo: o desejo exprime a maneira como a libido investe todo um campo social histórico, e como o desejo inconsciente enlaça seus últimos objetos".

O delírio não se constrói em torno do nome do pai, mas sobre zonas da história. Nomes próprios. Essas zonas são solos, ou gradientes de intensidade que o esquizofrênico atravessa no corpo sem órgãos (eu sinto que estou me tornando). Eles são designados por nomes de raças, continentes, planetas, classes (DELEUZE, 2003, p. 26).

Para que tal compreensão da esquizofrenia seja possível, Deleuze e Guattari precisaram não apenas colocar em questão as identificações freudianas e sua estrutura familiar representada por Édipo, mas a própria noção de eu, de corpo próprio, como unidade orgânica, esse que Édipo organiza positivamente, ou negativamente, com suas fases pré-genitais. É da crítica desta noção unitária, cuja função é racionalmente organizar o desejo atendendo ao mesmo tempo as demandas do supereu e do eu e a lei moral representada pelo primeiro, que surge o conceito de corpo sem órgãos. Ela visa romper a dicotomia entre indivíduo e social, para que o desejo não precise se submeter aos caprichos de um Outro transcendente, vivo ou morto, castrado ou castrador.

Deleuze e Guattari preferiram entender a esquizofrenia, não em função da destruição, ou das lacunas que ela introduz em uma estrutura, mas como um processo (DELEUZE, 2003, p. 26). A questão da esquizofrenia é "onde isso está me levando?" Não há aqui um eu capaz de julgar suas ações e a correspondência entre elas e seu desejo. Mas uma força que atravessa e move o corpo.

Quando Kraepelin definiu a demência precoce, ele não recorreu às causas, ou aos sintomas, ele a definiu como um processo com sua evolução e seu estado terminal. No entanto, este estado terminal seria uma desagregação completa e definitiva, o que justificava a internação onde o paciente esperaria pela morte. Já Karl Jaspers e Ronald D. Laing compreendem de outra maneira a natureza deste processo. Ela é "uma ruptura, uma irrupção, uma perfuração que quebra a continuidade de uma personalidade, levando-a a uma viagem de "mais-de realidade" (plus de réalité) intensa e aterradora, seguindo linhas de fuga onde mergulham natureza e história, organismo e espírito" (DELEUZE, 2003, 27)4.

4 Lacan (1966, p. 537), em "D'une question préliminaire à tout traitement possible de la psychose" (texto de referência nos anos 60 e setenta no que diz respeito à leitura lacaniana da psicose) define a teoria de Jaspers como uma "concepção falaciosa" porque para ele, em nenhum outro lugar, como na psicose, o sintoma "se sabemos lê-lo, é mais articulado à própria estrutura". E isso se deve, evidentemente, a experiência particular que o psicótico tem com a linguagem. Essa afirmação parece evidenciar a distância que separa Lacan de Guattari e Deleuze. 
Não se trata de um elogio à esquizofrenia, mas da compreensão de que ela é a doença da nossa época (DELEUZE, 2003, p. 27). E isso se deve a mecanismos muito precisos de natureza econômica, política e social.

Nossas sociedades não funcionam a base de códigos e territorializações, mas sob fundo de uma descodificação contínua e de uma desterritorialização massiva. O paranoico buscar restaurar os códigos e reinventar territorialidades, ele é a força reativa que luta contra a força desterritorializadora do próprio desejo, onde o capitalismo encontra sua face esquizofrênica.

O esquizofrênico não cessa de se desterritorializar, de se descodificar. Ele é o limite de nossa sociedade, mas um limite sempre conjurado, interrompido, reprimido, encarcerado. Ele é a figura de um desejo capaz de levar o Capital à lua e que dilacera completamente a imagem de um eu com função ordenadora. A imagem de um caos sem controle que deve ser esconjurado da vida social, porque ele oferece a imagem do dilaceramento do corpo social, de sua ordem e de suas razões, de seus aparatos e de suas práticas. É desta natureza a ação do capitalismo no interior da vida social e é essa sua natureza que requer a ação de um Estado "paranoico". O esquizofrênico é o limite porque é o que o corpo social mais teme para si mesmo e que ele não pode aceitar nem como forma de experiência subjetiva e individual.

Assim, a questão da esquizofrenia seria a que foi posta por Lang: como fazer para que a perfuração (breakthrough) não se torne dilaceramento ou quebra (break-down)? (DELEUZE, 2003, p. 27). Como fazer para que o corpo sem órgãos não se feche em si mesmo, catatônico? Onde estão suas linhas de fuga, sua potencialidade de fazer diferente?

As condições dos hospitais, assim como das famílias, são pouco satisfatórias neste sentido. Os sintomas negativos de autismo, perda da realidade, são frequentemente produzidos nos hospitais, ou nas famílias. A questão seria, portanto, saber se seria possível conjugar a potência química vivida e a análise para que o processo esquizofrênico não passe no seu contrário, ou seja, na produção de um esquizofrênico bom para o manicômio. Se isso for possível, a questão seria saber em que grupo, em que coletividade isso seria possível. Ou seja, não se trata apenas de colocar o sujeito, como pessoa, diante da verdade do seu desejo, mas de produzir através da análise, da esquizoanálise, formas de organização coletiva, formas de organização social, onde a produção desejante encontre lugar para aumentar sua potência de ação. Da mesma maneira que o desejo não será tomado como produção familiar e individual ele precisa ser pensado e analisado no interior da vida social, assim como as soluções possíveis para o aumento de sua capacidade de ação devem ser pensadas no interior da vida social. 


\section{Os lobos, J'ai fait un rêve}

Deleuze e Guattari, em "Un seul ou plusieurs loups?", não criticam a psicanálise apenas por ter selecionado os enunciados edípicos, mas por ter feito o paciente acreditar que ele poderia produzir enunciados pessoais, individuais, que ele poderia falar em seu nome. $\mathrm{O}$ homem dos lobos nunca conseguiu falar. Ele pode falar dos lobos, gritar como um lobo, Freud não escutava, ele olha para o seu cachorro e diz "é o pai". Enquanto isso dura, trata-se de neurose, quando tudo desmorona, é psicose.

É por essa razão que o homem dos lobos se sente tão cansado: ele continua deitado com todos os lobos na sua garganta, e todos os pequenos buracos em seu nariz, todos os seus valores libidinais no seu corpo sem órgãos. A guerra virá, os lobos vão se tornar bolcheviques, o Homem continua sufocado por tudo o que tinha a dizer (DELEUZE; GUATTARI, 1980, p. 52).

Ao final de seu relato, Freud (2010, p. 160) afirma que o paciente teve alta, curado, a seu ver, "poucas semanas" antes da Primeira Guerra. Ele o reencontrou quando as Potências Centrais tiveram acesso à Rússia meridional, após ter dominado uma parcela da transferência ainda não superada, após o fim do tratamento, o paciente "ao qual a guerra havia roubado a pátria, a riqueza e todas as relações familiares, sentiu-se normal e comportou-se impecavelmente. Talvez precisamente a sua miséria, ao satisfazer seu sentimento de culpa, tenha contribuído para firmar seu restabelecimento." O homem dos lobos, por outro lado, se vingará, afirmando que nada pode ter mais valor por um jovem do que o amor pela natureza e a compreensão da zoologia.

Freud teria esbarrado na verdade ao escrever, em 1915, "O inconsciente", onde distingue neurose e psicose. Freud afirma que um histérico, ou um obsessivo, é uma pessoa capaz de comparar globalmente uma meia a uma vagina, uma cicatriz à castração. Sem dúvida, isso ocorre ao mesmo tempo em que ele apreende o objeto como global e como perdido. Mas, apreender a pele como multiplicidade de poros, pequenos pontos, pequenas cicatrizes, apreender eroticamente a meia como multiplicidade de malhas, eis o que não passa pela cabeça do neurótico, enquanto o psicótico é capaz. Ele acreditava que a multiplicidade de pequenas cavidades impede o neurótico de utilizá-las como substituto dos órgãos genitais femininos. "Comparar uma meia a uma vagina, é coisa que fazemos todos os dias, mas comparar um puro conjunto de malhas com um campo de vaginas, é preciso ser mesmo louco" (DELEUZE; GUATTARI, 1980, p. 39). 
Essa seria a grande arte do inconsciente para Deleuze e Guattari, uma multiplicidade que transforma seus elementos, uma multiplicidade em devir. Mas Freud sempre retorna às unidades molares e aos temas familiares: o pai, a castração, a vagina, o pênis.

O que importa no devir-lobo é a posição de massa, a posição do "sujeito" diante da massa, diante da multiplicidade de lobos que o espreitava do topo da árvore. A questão é saber como ele penetra nessa massa, a distância que o separa dela, como ele sustenta ou não sustenta essa multiplicidade. $\mathrm{O}$ que Freud não percebia é que o inconsciente é antes de mais nada uma massa, uma multidão, uma multiplicidade de pequenas populações. A multiplicidade dos lobos nos remete, portanto, para Deleuze e Guattari, ao estatuto das formações do inconsciente. A questão é saber que fatores interferem aqui.

Em primeiro lugar, algo que faz o papel do corpo pleno - corpo sem órgãos. A árvore e os galhos onde estão os lobos. "Ninguém faz amor com amor sem constituir para si, com outro ou outros, um corpo sem órgãos. Este corpo "não é vazio ou desprovido de órgãos, mas um corpo onde o que serve de órgão (lobos, olhos de lobos, mandíbula de lobos) se distribuem a partir de fenômenos de massa, seguindo movimentos brownoïdes, sob a forma de multiplicidades moleculares" (DELEUZE; GUATTARI, 1980, p. 43).

Não se trata de pensar o desejo a partir de pessoas organizadas com órgãos genitais que determinam sua posição diante do outro, sua escolha de objeto e a experiência da inexorável dissimetria entre os sexos. O desejo não se reduz ao sexo ou a sexualidade entre "pessoas". Assim, colocar em questão a unidade do corpo e o binarismo do sexo significa também colocar em questão a imagem do corpo próprio e sua organização sob a forma do organismo, onde os órgãos funcionam mecanicamente como unidades capazes de agir como uma unidade maior para, em concerto, manter a homeostase. "O corpo pleno sem órgãos é um corpo povoado de multiplicidades. E o problema do inconsciente, com certeza, não está ligado à geração, mas ao povoamento, à população" (DELEUZE; GUATTARI, 1980, p. 43). O esquizofrênico não tem uma mãe e um pai como tais, mas um deserto e as múltiplas tribos que o habitam.

A segunda questão, diz respeito à natureza desta multiplicidade e de seus elementos. Cada elemento está em constante movimento, por isso ele não cessa de variar e modificar a sua distância em relações aos outros. Cada divisão ou modificação é uma transformação de natureza. O caráter intensivo desta multiplicidade que habita e transita pelo espaço do corpo sem órgãos se deve ao fato de que elas não povoam um meio homogêneo. Elas são afetadas por forças que as atravessam. Mesmo Freud é capaz de reconhecer a multiplicidade das correntes que 
passam pelo homem dos lobos, daí o espanto de Deleuze e Guattari com as reduções que ele opera.

Essa multiplicidade não poderia ser reduzida aos pares binários mãe/ pai, vagina/pênis, édipo/castração. Elas deveriam ser compreendidas como intensidades: "o Lobo é matilha, ou seja, a multiplicidade entendida como tal em um instante, a partir de sua aproximação ou distanciamento do ponto zero - Distâncias cada vez indecomponíveis. O Zero é o corpo sem órgãos do homem dos lobos" (DELEUZE; GUATTARI, 1980, p. 44). Isso implica que as experimentações que o homem dos lobos desejava diziam respeito aos lobos que o habitavam, as distâncias entre esses lobos e seu corpo sem órgãos contém séries de possibilidades, ilimitados mundos possíveis que reclamam a luz do dia, e que, evidentemente não se limitam à sexualidade sob sua forma antropomórfica, essas possibilidades podem produzir intensidades igualmente ilimitadas que precisam (é que o desejo reclama) ser experimentadas para serem julgadas e selecionadas.

Vimos que Sergueï afirmava que a psicanálise não disse nada sobre seus sonhos. Para Deleuze e Guattari, o homem dos lobos contava nesse sonho sobre as populações que o habitavam. Os lobos designavam um bando de intensidades, um patamar de intensidade, eles dizem: eu sinto. "Sinto que me torno lobo, lobo entre os lobos, na moldura dos lobos, e o grito de angústia, o único que Freud escuta: ajude-me a não me tornar lobo (ou ao contrário a não fracassar nesse devir)" (DELEUZE; GUATTARI, 1980, p 45).

A angústia é o sinal de um encontro com uma novidade indiscernível. Como viver este devir? Como experimentar essas forças que agitam seu corpo e parecem ameaçar seu funcionamento e constituição? Os lobos são intensidades, velocidades, temperaturas, distâncias variáveis e indecomponíveis. A multiplicidade é justamente um processo de desterritorialização que atravessa o corpo, a questão é saber como ela funciona e o que ela é capaz de produzir. Esse sonho que dá voz a uma máquina desejante, que faz manifestar-se um inconsciente abre espaço para séries de experimentações.

O homem dos lobos não diz outra coisa quando no final de sua vida reflete sobre a psicanálise e sua importância em sua trajetória:

No que diz respeito ao que aconteceu, eu tenho a impressão que uma mudança só pode intervir se temos a experiência de algo que refuta aquilo com o que nos acostumamos. Mas só a lembrança, na minha opinião, não serve de nada. Eu acredito que uma transformação pode surgir de uma experiência, experiência real, não apenas em pensamento, enquanto representação. Isso não é suficiente (OBHOLZER, 1981, p. 186). 
As multiplicidades inconscientes não são extensivas, divisíveis, molares, unificáveis, totalizáveis, organizáveis. Elas são intensivas, múltiplas, constituídas de partículas que se dividem transformando sua natureza, de distâncias que não variam sem entrar em contato com outra multiplicidade, que se fazem e se desfazem comunicando-se, passando além de um solo, ou aquém ou adiante. A questão é saber o que fazer com essa população que me atravessa. E o esquizô tem uma maneira particular de lidar com multiplicidades. Deleuze e Guattari partem de uma distinção feita por Elias Canetti, a respeito de dois tipos de multiplicidades, para explicar a natureza da multiplicidade que move e habita o esquizô.

Elias Canetti descreveu dois tipos de multiplicidades que podem tanto se opor quanto se interpenetrar: de massa e de motim. As multiplicidades de massa tem as seguintes características: são em grande quantidade, divisíveis, há igualdade entre os membros, concentração, sociabilidade do conjunto, unicidade da direção hierárquica, organização de territorialidade e territorialização, emissão de signos. As massas se organizam delimitando, circunscrevendo, marcando os espaços, estabelecendo posições rígidas e lugares unívocos.

As massas de tipo motim são pequenas, de número restrito, dispersas, estão em distâncias indecomponíveis, apresentam metamorfoses qualitativas, as desigualdades são restos ou travessias, impossibilidade de totalização ou hierarquização fixa, variedade browniana de direções, linhas de desterritorialização, projeção de partículas. O líder do motim ou de bando coloca tudo em jogo a cada passo, enquanto que o chefe da massa consolida e capitaliza em cima do que foi conquistado. O motim, mesmo no seu lugar, se constitui a partir de uma linha de fuga e de desterritorialização, essa linha faz parte dele e tem um alto valor positivo, já as massas integram linhas para segmentá-las, bloqueá-las, afetá-las com um signo negativo.

São dois modos de organização que não dependem da geração ou da filiação, no entanto, o que os distingue é justamente a possibilidade de existência de uma hierarquia fixa e suas consequências na natureza da multiplicidade. Há também a posição de cada indivíduo no interior dessas multiplicidades. No bando ou motim cada um fica sozinho estando, portanto, com os outros. Cada um cuida do que lhe interessar estando, ao mesmo tempo, no bando. Nas constelações em mutação do bando, o indivíduo permanece na fronteira. Ele estará dentro e de repente, perto do limite, na borda e, em seguida, dentro, mas em outro lugar. Essa é a posição esquizofrênica, um estar sempre na periferia, no limite. A posição paranoica é diferente, nela imperam as identi- 
ficações entre indivíduo e chefe. O importante, para cada membro é estar cada vez mais no interior da massa, cada vez mais perto do centro, jamais à distância a não ser seguindo ordens (DELEUZE; GUATTARI, 1980, p. 47).

Essas multiplicidades não são excludentes, as multiplicidades de multiplicidades formam um mesmo agenciamento, são exercidas em um mesmo agenciamento, os bandos nas massas e inversamente. Também não se trata de uma relação entre um indivíduo e um grupo ou inversamente, a distinção não diz respeito à relação entre interior e exterior, mas entre multiplicidades. $E$ no que diz respeito ao inconsciente, assim como à vida social, nos deparamos sempre com arranjos entre multiplicidades de naturezas distintas, esse é o jogo de forças que mobiliza a natureza e a História. Se não há enunciado individual, se todo enunciado é produto de um agenciamento maquínico, ou seja, de agentes coletivos de enunciação é porque eles são produzidos por multiplicidades (DELEUZE; GUATTARI, 1980, p. 51) O homem dos lobos adquiriria seu nome próprio a partir de um exercício de despersonalização ou desterritorialização, os lobos são o nome deste processo, nome "íntimo que envia aos devires, infinitivos, intensidades de um indivíduo despersonalizado e múltiplo" (DELEUZE; GUATTARI, 1980, p. 51).

\section{Considerações finais}

A tese da esquizoanálise é de que o desejo é máquina (porque composto de multiplicidades distintas), máquina desejante que é ação, produção (daí a importância dos devires no infinitivo, eles são verbos, ações). O momento positivo da esquizoanálise, que "falta" à psicanálise, consiste em descobrir a natureza, a formação e o funcionamento das máquinas desejantes.

Vimos que mesmo Freud parece ter se dado conta de um elemento qualitativo da libido que a torna demasiado líquida para se manter na triangulação edípica. Isso que subjaz e anima os corpos, no caso do homem dos lobos, os lobos, é chamado de máquina desejante. Esse processo, que escapa dos pares duais postos por Édipo e pela castração que dele decorre, requer uma análise distinta da interpretação psicanalítica. Não se trata de interpretar o desejo através da questão "o que isso quer dizer?", não estamos diante de um inconsciente que se exprime, mas de um inconsciente produzido que precisa ser pensado a partir, justamente de suas produções, o que implica que a questão posta pelo esquizo-analista seria "como isso funciona?" (DELEUZE; GUATTARI, 1972, p. 132). 
A psicanálise concebe o inconsciente como "uma contra-consciência, um negativo, um parasita da consciência" ${ }^{\text {. O }} \mathrm{O}$ inimigo. "Wo es war, soll ich werden". Mesmo traduzindo: lá onde era/estaria, lá como sujeito deve tornar-se - não muda nada, mesmo o "soll", este estranho "dever no sentido moral". "O que a psicanálise chama de produção inconsciente é sempre os fracassos, os conflitos imbecis, os compromissos débeis ou grandes jogos de palavras." (DELEUZE, 2003, p. 73).

Deleuze continua a crítica afirmando que todo sucesso é sempre caracterizado como sublimação, ou seja, dessexualização, pensamento, obra de arte, mas nunca é do desejo que se trata. O desejo é o inimigo que assombra do coração do inconsciente. O desejo é sempre excessivo, daí a figura do "perverso polimorfo". A psicanálise nos ensina sobre a Falta, a Cultura e a Lei, ou seja, ela reduz e abole o desejo.

O caso do homem dos lobos é exemplar, porque Deleuze e Guattari sustentam que a cena do sonho não deve ser lida em relação com a dita cena primária ou fantasia. Os lobos, no plural, são um agenciamento, uma tentativa de trazer à vida um desejo possível, uma linha de fuga que atrai, inquestionavelmente, o desejo do homem que se tornaria o homem dos lobos. Essa tentativa é restringida por Freud quando vê, insistentemente, a mesma cena como chave de toda a interpretação, chave edípica, que faz que o desejo que era linha de fuga retorne ao recôndito do lar.

Por essa razão, o inconsciente, "vocês não o possuem, vocês nunca tiveram um, ele não é um "seria ou estaria" a partir do qual o "Eu" ou um "sujeito" emergiria. "É preciso inverter a fórmula de Freud, o inconsciente, vocês devem produzi-lo, criem-no" (DELEUZE, 2003, p. 73).

É desta maneira que Deleuze \& Guattari analisam o caso do homem dos lobos, eles procuram nos sonhos que ele ignora ou alega ter esquecido, e sobre o qual a psicanálise não lhe disse nada, suas máquinas desejantes. Os lobos aparecem aqui como um caminho possível, do qual Sergueï se desviou e que ele nunca foi capaz de retomar.

Para que o inconsciente possa ser produzido ele precisa se desvencilhar das representações. Assim, a crítica de Édipo, em linhas gerais, tem como objetivo demonstrar a terceira tese da esquizoanálise,

\footnotetext{
5 Se a afirmação deleuziana parece excessiva, podemos lembrar essa afirmação lacaniana, ela descreve um caso de loucura que começou com o sintoma fala imposto. Podemos encontrála no seminário XXIII onde Lacan trata de Joyce: "É assim que o paciente articula este algo que parece ser tudo o que há de mais sensato na ordem, na ordem de uma articulação que eu posso chamar de lacaniana. Como é que nós não sentimos todos que falas das quais nós dependemos nos são de alguma maneira impostas. É nisso que o que chamamos de doente vai, às vezes, mais longe do que o que chamamos de homem normal. A questão é saber por que um homem normal, dito normal, não percebe que a fala é um parasita; um embuste; que a fala é uma forma de câncer do qual o ser humano padece. Como é que alguns são capazes inclusive de sentir?" (LACAN, 2005, p. 95).
} 
que postula o primado dos investimentos libidinais do campo-social sobre o investimento familiar, tanto do ponto de vista do fato como do direito, estímulo qualquer no início, resultado extrínseco na chegada. A relação ao não-familiar é sempre primeira, sob a forma da sexualidade de campo na produção social, e do sexo não humano na produção desejante (gigantismo e nanismo) (DELEUZE; GUATTARI, 1972, p. 430-431).

Basta olhar para a imagem que se constrói da sexualidade a partir do complexo para que possamos compreender a natureza desta limitação. A castração é uma representação antropomórfica e molar do sexo, isso porque ela coloca o problema da escolha de objeto, ou da posição do desejo, como uma escolha entre pares binários construídos a partir de uma matriz pessoal e biológica, restrita, portanto, aos corpos orgânicos e às pessoas organizadas, homem/mulher. Desta dicotomia derivam muitas outras como passivo/ativo, heterossexual/homossexual, sádico/ masoquista.

Já para Deleuze e Guattari, as identificações pensadas a partir da esquizofrenia não se restringem ao par, papai-mamãe e suas repetições na vida social. Elas são primeiramente sociais e históricas, assim como o sexo é múltiplo. O esquizo delira com as raças, os continentes e a história porque os investimentos sociais são sempre de grupo, nunca individuais e se endereçam à história e à geografia.

Neste ponto, deparamo-nos com a dimensão política da esquizoanálise e seu lugar no interior da crítica das instituições. A questão seria, portanto, construir espaços e formas de organização coletiva no interior dos quais a esquizofrenia encontraria lugar para se tornar efetivamente produtiva, é o que Guattari chama de criatividade institucional. Se a família e os muros dos hospícios produzem apenas catatonia, como fazer para que essa quebra seja evitada e se torne travessia?

As distinções entre massa e bando ou motim e entre grupo sujeito e grupo sujeitado visam justamente explorar as diferenças entre formas distintas de organização de multiplicidades. A análise institucional é política porque interroga formações de grupo de natureza distintas, seja no hospital, seja nas organizações políticas visando encontrar as formas de organizações onde um desejo encontre lugar para desdobrar-se e multiplicar-se.

\section{Referências}

DELEUZE, G. Deux régimes des fous. Textes et entretiens, 1975-1995. Org. David Lajoujade. Paris: Éditions du Minuit, 2003.

DELEUZE. G.; GUATTARI, F. Anti-Edipe. Paris: Éditions du Minuit, 1972.

. Mille Plateaux. Paris: Éditions du minuit, 1980. 
FREUD, S. História de uma neurose infantil ("O homem dos lobos"). Além do princípio do prazer e outros textos. Trad. de Paulo César de Souza. São Paulo: Companhia das Letras, 2010.

GABARRON-GARCIA, Florent. "'L'anti-oedipe”, un enfant fait par Deleuze-Guattari dans le dos de Lacan, père du 'Sinthome'”. Chimères, 72, 1 (2010), p. 303-320.

GARDINER, Muriel. The wolf-man and Sigmund Freud. Penguin: Middlesex, 1973.

LACAN, J. Écrits. Paris: Seuil, 1966. . Le sinthome. Le Séminaire. Livre XXIII. Paris: Seuil, 2005.

OBHOLZER, Karin. Entretiens avec l'homme aux loups. Une psychanalyse et ses suites. Paris: Gallimard, 1981.

SAURET, Marie-Jean. "Les Hommes aux loups". Psychanalyse, 2, 1 (2005), p. 53-82. . "Les 'loupés' de l'Homme aux loups". Psychanalyse, 21, 2 (2011), p. 5-20.

\section{Endereço postal:}

Departamento de Filosofia - USP

Rua do Lago, 717 - Vila Universitária

São Paulo, SP, Brasil

Data de recebimento: $12-04-2017$

Data de aceite: 04-09-2017 